\title{
Simulation of Stream Flow for Upper Lam Takongsub-Watershed Using SWAT Model
}

\author{
Netnapa Pongpetch and Pongthep Suwanwaree
}

\begin{abstract}
Watershed is considered to be the idea unit for water management. The Soil and Water Assessment Tool (SWAT) interfaced with ArcGIS 9.3 software (ArcSWAT2009) was selected for stream flow estimation from Upper Lam Takong, a part of the Moolbasin, in Northeastern region of Thailand. This sub-watershed has a total area of $581 \mathbf{k m}^{2}$. The model was calibrated for the year 2007-2008 and validated with observed stream flow for the year 2009. Then the model performance was evaluated using statistical and graphical methods to assess model simulation capability for the study area. The Nash-Sutcliffe model efficiency (NSE) coefficient and the regression correlation coefficient $\left(\mathbf{R}^{2}\right)$ for monthly stream flow were obtained as 0.85 and 0.86 for calibration period and 0.63 and 0.92 for validation period, which showed that SWAT model can be a useful tool for water resource management in Upper Lam Takongand the bigger Lam Takong watershed.
\end{abstract}

Index Terms - Model, Stream flow, SWAT, Watershed.

\section{INTRODUCTION}

Watershed managers, tasked with implementing strategies for controlling point source (PS) and non-point source (NPS) pollution, need a water quality model that can correctly identify the locations where runoff is generated in order to effectively place best management practices (BMPs) [1]. The basic requirement for this model is its capability to estimate surface runoff adequately because the surface runoff process affects the transport of sediments and agricultural chemicals [2]. The Soil and Water Assessment Tool (SWAT) model is one of the most commonly used and well supported water quality modeling, physically based, computationally efficient, and capable of continuous simulation over long time periods. Its major components include weather, hydrology, soil temperature and properties, plant growth, nutrients, pesticides, bacteria and pathogens, and land management models [3]. This model has proven to be an effective tool for assessing water resource and non-point source pollution problems, particularly those dominated by agriculture [4], [5] Compared to the simulation for stream flow, simulation of sediment erosion and transport throughout a catchment is a challenging task [2]. In Thailand, water pollution is largely associated with urbanization, industrialization and agricultural activities. The main pollutants for surface water quality problems are sediments, nutrients and other chemical substances [6]. In this study, the Upper Lam Takong

Manuscript received December 10, 2012; revised February 27, 2013. This work was supported by the Strategic Scholarships of Frontier Research Network for the Joint Ph.D. Program from the Commission on Higher Education and Suranaree University of Technology, Thailand.

The authors are with School of Biology, Institute of Science, Suranaree University of Technology, NakhonRatchasima, Thailand (e-mail: netna_love@hotmail.com, pongthep@sut.ac.th). sub-watershed, which is located at the upstream of Lam Takong watershed and Lam Takong reservoir, is selected as the study area to estimate both flow and sediment loading. However, this paper focuses only on flow study, to evaluate SWAT prediction capabilities for stream flow in Upper Lam Takong. SWAT is selected because of its availability and user-friendliness in handing input data [5]. In addition, hydrology models have not been widely performed in Thailand, especially SWAT model. The result obtained in this study will provide a scientific basis for water resource planning and management, as well as measures to control soil losses in the study area.

\section{MATERIALS AND MethodS}

\section{A. Description of Study Area}

The Upper Lam Takong has a total area of $581 \mathrm{~km}^{2}$, a part of Lam Takong watershed (Fig. 1) which is a part of MoolRiver watershed, an important basin of Northeastern Thailand [7].

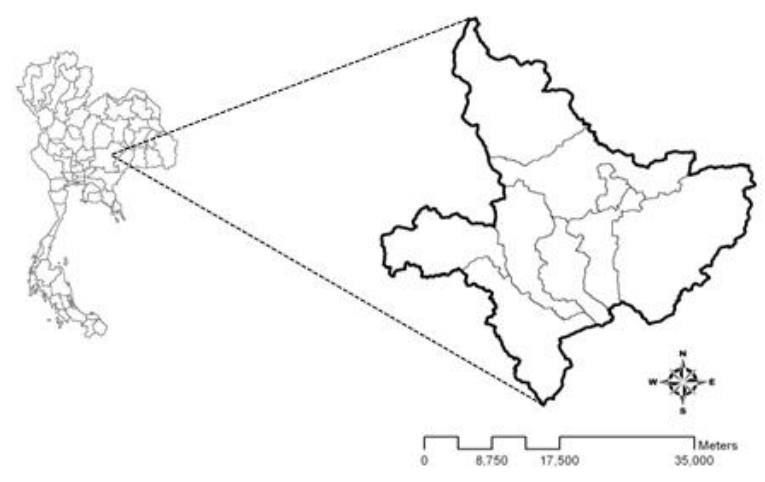

Fig. 1. Location of Upper Lam Takong.

Upper Lam Takong is under the influence of southwest and northeast monsoon. There are three seasons including rainy, winter and summer season [8]. From May to October, the southwest monsoon brings moisture from the Indian Ocean that falls as rain, peaking in August and September [9]. The average amount of rainfall is $1,454.3 \mathrm{~mm}$ [10]. While from October to February, the wind direction is reversed and a cooler, drier northeast monsoon wind blows off the Asian landmass, bringing a cold season. Temperature falls slightly with short transitional period between the monsoons during March and April. This is the hottest period of the years [9]. Upper Lam Takong has $25.4^{\circ} \mathrm{C}$ average temperature, 1,379.4 $\mathrm{mm} /$ year evaporation, 83.4 and $47.8 \%$ of maximum and minimum relative humidity, respectively.

Land use is dominated by forest land and agricultural land. The forest land area occupies over $46.54 \%$ and agriculture over $37.55 \%$ (Table I). The soils contain many soil series, 
such as, KhaoYai, Kabinburi, Khorat and Lam Narai series. Soil drainage is medium to good. Soil layer has alternately shallow and deep with medium fertility [10].

TABLE I: PERCENTAGE OF LAND USE TYPES IN UPPER LAM TAKONG BASIN [11].

\begin{tabular}{lc}
\hline \hline \multicolumn{1}{c}{ Land use types } & Percentage of total area \\
\hline Forest land & 46.54 \\
Agricultural land & 37.55 \\
Urban land & 6.25 \\
Industrial land & 4.05 \\
Miscellaneous land & 5.49 \\
Water body & 0.12 \\
Total & $\mathbf{1 0 0 . 0 0}$ \\
\hline \hline
\end{tabular}

\section{B. SWAT Model Description}

SWAT is a hydrologic/water quality model developed by United States Department of Agriculture and Agricultural Research Service (USDA-ARS) [5]. SWAT can predict the impact of land management practices on water, sediment and agricultural chemical yields in large complex watersheds with varying soils, land use and management conditions over long periods of time [12]. In SWAT, a watershed is divided into multiple sub-basins, which are further subdivided into hydrologic response units (HRU) that consist of homogeneous land use, management and soil characteristics. Stream-flow generation, sediment yield and nonpoint source loadings from each HRU are summed and the resulting loads are routed through channels, ponds, and/or reservoirs to the watershed outlet. Key components of SWAT include hydrology, plant growth, erosion, nutrient transport and transformation, pesticide transport and management practices. Outputs provided by SWAT include stream-flow and in-stream loading or concentration estimates of sediment, organic nitrogen, nitrate, organic phosphorus, soluble phosphorus and pesticides [3].

SWAT also uses the Green-Ampt infiltration method or a modified version of Soil Conservation Service Curve Number (SCSCN) method for runoff prediction [13].

\section{Stream Flow Calibration and Validation}

SWAT model was calibrated and validated in years 2007-2008 and 2009, respectively, by using the observed stream flow data at M89 station in Upper Lam Takong provided by the Hydrology and Water Management Center for Lower Northeastern Region, NakhonRatchasima, Thailand.

Then model calibration and validation were evaluated by the coefficient of determination $\left(\mathrm{R}^{2}\right)$ and the Nash-Sutcliffe model efficiency coefficient (NSE) [14].

\section{RESUlts AND DisCUSSION}

\section{A. Model Calibration}

Parameter calibration: Parameters affecting the stream flow were calibrated until the simulated monthly flow closely matched the observed data. Nine input parameters were calibrated for flow process (Table II). ESCO and SURLAG were set from 0.95 to 0.5 and 4 to 0.5 , respectively. GW_DELAY, ALPHA_BF, GE_REVAP and RCHRG_DP were adjusted from 31 to $42,0.048$ to $0.55,0.02$ to 0.056 and 0.05 to 0.56 , respectively, which control subsurface water processes. CN2 was decreased $5 \%$. This parameter governs surface water processes. In addition, the routing processes influenced parameters, including Manning's roughness coefficient in main channel routing ( $\left.\mathrm{CH}_{-} \mathrm{N} 2\right)$ was changed from 0.14 to 0.6 . Varied roles of $\mathrm{CH}_{-} \mathrm{N} 2$ in SWAT simulations suggest a considerable difference in topography, stream channel geomorphology and riparian vegetation [15], [16].

TABLE II: INPUTS USED IN MODEL CALIBRATION.

\begin{tabular}{|c|c|c|c|c|}
\hline $\begin{array}{l}\text { Variable } \\
\text { Name }\end{array}$ & $\begin{array}{l}\text { Model } \\
\text { Process }\end{array}$ & Description $^{1}$ & Default & $\begin{array}{l}\text { Actual } \\
\text { Value }\end{array}$ \\
\hline ESCO & Flow & $\begin{array}{l}\text { Soil evaporation } \\
\text { compensation factor. }\end{array}$ & 0.95 & 0.5 \\
\hline SURLAG & Flow & $\begin{array}{l}\text { Surface runoff lag } \\
\text { coefficient. }\end{array}$ & 4 & 0.5 \\
\hline GW_DELAY & Flow & $\begin{array}{l}\text { Groundwater delay } \\
\text { time (days). }\end{array}$ & 31 & 42 \\
\hline ALPHA_BF & Flow & $\begin{array}{l}\text { Baseflow alpha factor } \\
\text { (days). }\end{array}$ & 0.048 & 0.55 \\
\hline GW_REVAP & Flow & $\begin{array}{l}\text { Groundwater "revap" } \\
\text { coefficient. }\end{array}$ & 0.02 & 0.056 \\
\hline RCHRG_DP & Flow & $\begin{array}{l}\text { Deep aquifer } \\
\text { percolation fraction. }\end{array}$ & 0.05 & 0.56 \\
\hline $\mathrm{CN} 2$ & Flow & Curve number & Varies $^{2}$ & $-5 \%$ \\
\hline CH_N2 & Flow & $\begin{array}{l}\text { Manning's "n" value } \\
\text { for the main channel. }\end{array}$ & 0.14 & 0.6 \\
\hline SOL_ALB & Flow & Moist soil albedo. & 0.2 & 0.12 \\
\hline
\end{tabular}

${ }^{1}$ Detailed description is in "Soil and Water Assessment Tool User's Manual Version 2000'[17].

${ }^{2}$ Varies by land use and hydrologic soil group.

Stream flow: After calibration, the monthly observed and simulated flows in Upper Lam Takong matched very well (Fig. 2). Further an acceptable calibration for good model performance were shown by the coefficient of determination and NSE greater than 0.85 (Table III). These results showed that the hydrological processes in SWAT were realistically simulated in the study area. It is generally reasonable to conclude that the SWAT simulations calibrated at a monthly time steps are reasonably good, and the calibrated model maybe employed for further analysis. However, the simulated runoff was generally lower than the corresponding observed values during periods with concentrated rainfall.

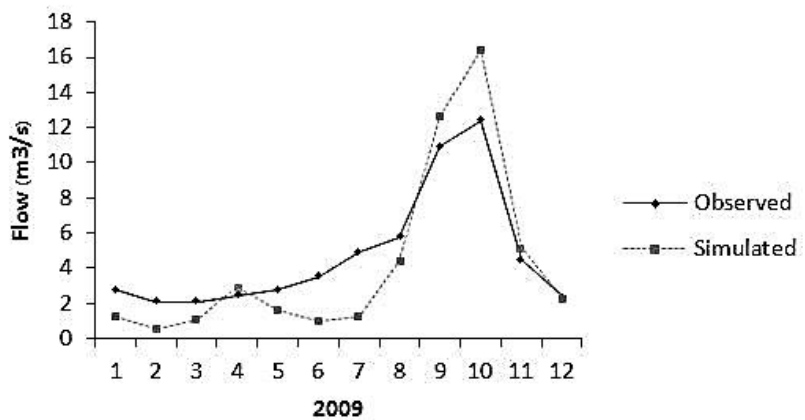

Fig. 2. Observed and simulated monthly flows during calibration period.

TABLE III: MODEl PERFormanCE FOR THE Simulation OF StREAM FLOW.

\begin{tabular}{lccccc}
\hline \hline \multirow{2}{*}{ Results } & \multicolumn{2}{c}{ Mean $\left(\mathrm{m}^{3} / \mathrm{s}\right)$} & & \multirow{2}{*}{$\mathrm{R}^{2}$} & \multirow{2}{*}{ NSE } \\
\cline { 2 - 3 } & Observed & Simulated & & \\
\hline Calibration (2007-2008) & 148.63 & 148.13 & 0.86 & 0.85 \\
Validation (2009) & 56.54 & 50.46 & 0.92 & 0.63 \\
\hline \hline
\end{tabular}




\section{B. Model Validation}

Stream flow: The monthly observed and simulated flows in Upper Lam Takong also matched very well (Fig. 3). Further an acceptable validation as satisfactory hydrology model were shown by the coefficient of determination and NSE greater than 0.63 (Table III). Although the statistical evaluation showed the satisfactory runoff simulation for validation period, SWAT tended to overestimate the runoff during high-flow periods. This could be partly because the present curve number technique is unable to generate accurate runoff prediction for a day that experience several storms. When several storms occur during a single day, the soil moisture level and the corresponding runoff curve number vary from storm to storm [18].

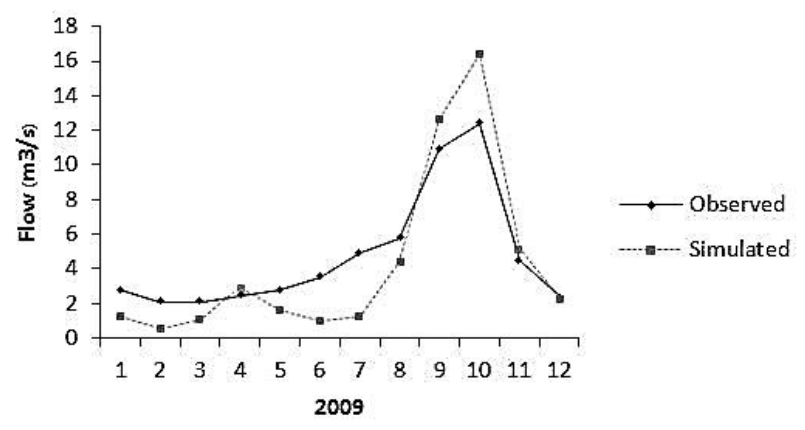

Fig. 3. Observed and simulated monthly flows during validation period

\section{CONCLUSION}

The SWAT model was applied to evaluate the prediction capability for stream flow in Upper Lam Takong sub-watershed. The monthly measured discharge at M89 station of the Hydrology and Water Management Center for Lower Northeastern Region, NakhonRatchasima, Thailand, were calibrated and validated in 2007-2008 and 2009, respectively. Calibration and validation results of the SWAT model showed that the simulated monthly flows were in reasonable agreement with measured values. Therefore, the SWAT model could be accurately used to simulate stream flows in the study area and the entire Lam Takong River basin.

\section{ACKNOWLEDGMENT}

The authors gratefully acknowledge the Office of the Higher Education Commission, Thailand for the grant fund under the program Strategic Scholarships for Frontier Research Network for the Ph.D. Program Thai Doctoral degree for this research. We also appreciate the generous cooperation of the Hydrology and Water Management Center for Lower Northeastern Region, NakhonRatchasima, the Land Development Department, the Royal Irrigation Department and the Thai Meteorology Department.

\section{REFERENCES}

[1] Z. M. Easton, D. R. Fuka, M. T. Walter, D. M. Cowan, E. M. Schneiderman, and T. S. Steenhuis, "Re-conceptualizing the Soil and Water Assessment Tool (SWAT) model to predict runoff from variable source areas," Journal of Hydrology, vol. 348, no. 3-4, pp. 279-291, 2008.

[2] Z. X. Xu, J. P. Pang, C. M. Liu, and J. Y. Li, “Assessment of runoff and sediment yield in the Miyun Reservoir catchment by using SWAT model," Hydrological Processes, vol. 23, pp. 3619-3630, 2009.

[3] P. W. Gassman, M. R. Reyes, C. H. Green, and J. G. Arnold, "The Soil and Water Assessment Tool: historical development, applications, and future research directions," American Society of Agricultural and Biological Engineers, vol. 50, no. 4, pp. 1211-1250, 2007.

[4] J. G. Arnold and N. Fohrer, "SWAT 2000: Current capabilities and research opportuniyies in applied watershed modeling," Hydrological Processes, vol. 19, no. 3, pp. 563-572, 2005.

[5] J. G. Arnold, R. Srinivasan, R. S. Muttiah, and J. R. Williams, "Large area hydrologic modeling and assessment part I: model development," American Water Resources Association, vol. 34, no. 1, pp. 73-89, 1998.

[6] Department of Environmental Quality Promotion. (2005). Thailand environmental performance assessment. [Online]. Available: http://www.deqp.go.th/SepII/SepII.htm.

[7] Regional Environment Office 11, "The workshop of Lam Takong River restoration strategic movement," (in Thai), 2010.

[8] Royal Irrigation Department, "Briefing document of Lam Takong water transmission and maintenance project," NakhonRatchasima: Irrigation 8 NakhonRatchasima, (in Thai), 2004.

[9] Thai Meteorological Department. (2008). Thailand annual weather summary. [Online]. Available: http://www.tmd.go.th.

[10] Lamtakong Watershed Research Station. (2010). Lamtakong watershed research station. [Online]. Available: http://www.dnp.go.th/Ferd/ferdTHAI/lamta kong_watershed_station.html.

[11] Land Development Department, "NakhonRatchasima Database," Land Development Department, Thailand, 2008.

[12] S. L. Neitsch, J. G. Arnold, J. R. Kiniry, and J. R. Williams, Soil and Water Assessment Tool theoretical documentation version 2009, Texas Water Resources Institute, College Station, Texas, 2011.

[13] S. C. S. US Department of Agriculture, Natiional Engineering Handbook, Hydrology Section 4, Chapters 4-10, 1972.

[14] D. A. Chekol, B. Tischbein, H. Eggers, and P. Vlek, "Application of SWAT for assessment of spatial distribution of water resources and analyzing impact of different land management practices on soil erosion in Upper Awash River Basin Watershed," Paper presented at the Catchment and Lake Research, 2007.

[15] K. B. Vaché, J. M. Eilers, and M. V. Santelman, "Water quality modeling of alternative agricultural scenarios in the U.S. Corn Belt," Journal of the American Water Resources Association, vol. 38, no. 3, pp. 773-787, 2002.

[16] K. Wu and Y. J. Xu, "Evaluation of the applicability of the SWAT model for coastal watersheds in Southeastern Louisiana," Journal of the American Water Resources Association, vol. 42, no. 5, pp. 1247-1260, 2006.

[17] S. L. Neitsch, J. G. Arnold, J. R. Kiniry, R. Srinivasan, and J. R. Williams, Soil and Water Assessment Tool user's manual version 2000, Texas Water Resources Institute, College Station, Texas, 2002.

[18] N. W. Kim and J. Lee, "Temporally weighted average curve number method for daily runoff simulation," Hydrological Processes, vol. 22, no. 25, pp. 4936-4948, 2008.

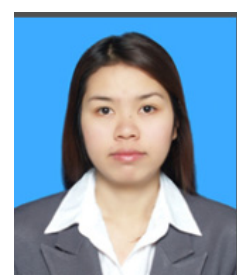

Netnapa Pongpetch was born in Loei Province, Thailand, on Sep. 12, 1985. She graduated with a bachelor's degree in Environmental Science, Khon Kean University, Thailand, and she is a $\mathrm{PhD}$ student in School of Biology at Suranaree University of Technology, NakhonRatchasima, Thailand. 